\title{
UNDERGROUND WATER FLOW BETWEEN BLOKE PLATEAU AND CERKNICA POLJE AND HYDROLOGIC FUNCTION OF KRIŽNA JAMA, SLOVENIA
}

\author{
PODZEMNI TOK MED BLOŠKO PLANOTO IN CERKNIŠKIM \\ POLJEM IN HIDROLOŠKA FUNKCIJA KRIŽNE JAME, SLOVENIJA
}

\author{
Janja KOGOVŠEK ${ }^{1} \&$ Mitja PRELOVŠEK ${ }^{1} \&$ Metka PETRIČ $^{1}$
}

\begin{abstract}
UDC 556.34.04(497.4)

Janja Kogovšek, Mitja Prelovšek \& Metka Petrič: Underground water flow betwen Bloke plateau and Cerknica polje and hydrologic function of Križna jama, Slovenia

Križna jama and Križna jama 2 are of important natural value. They have been known for more than hundred years from speleobiological, paleontological, geomorphological and touristic points of view. In 2007 the establishment of a water treatment plant on Bloke plateau raised important question: can partly cleaned water from the water treatment plant contaminate both caves and decrease their value? To answer this question a tracer test was carried out at the Bloke plateau. It showed general underground water flow from Farovščica ponor at Bloke plateau toward the Šteberščica spring at Cerknica polje. Minority of recovered tracer appeared at Žerovniščica and Izvir v Podložu springs. The tracer was not detected at Studenec v Ložu and Zlatovec springs. Between ponor and springs three karst caves were observed. The highest concentration of tracer was detected in the cave Mrzla jama pri Bločicah and a much smaller concentration in the Križna jama and Križna jama 2. This shows that at middle water level the underground Farovščica stream does not flow directly through Križna jama and Križna jama 2 but near or below them. Since the tracer appeared in both caves only after the precipitation, underground water course can be significantly different at high water level. Tracing test also showed some characteristics of underground water flow through dolomite and characteristics of a composed aquifer with alogenic-autogenic recharge.

Key words: tracer test, dolomite aquifer, pollution risk, Križna jama, Slovenia.
\end{abstract}

Izvleček

UDK 556.34.04(497.4)

Janja Kogovšek, Mitja Prelovšek \& Metka Petrič: Podzemni tok med Bloško planoto in Cerkniškim poljem in hidrološka funkcija Križne jame, Slovenija

Križna jama in Križna jama 2 sta pomembni naravni vrednoti znani s speleobiološkega, paleontološkega, geomorfološkega in turističnega vidika. Leta 2007 se je $\mathrm{z}$ gradnjo čistilne naprave pri Fari na Bloški planoti odprlo pomembno vprašanje, ali lahko delno očiščena voda pripelje do onesnaženja obeh jam in tako zmanjša njuno vrednost. Zaradi tega je bil decembra 2007 izveden sledilni poskus z Bloške planote. Pokazal je, da vode Farovščice na Blokah odtekajo predvsem v izvir Šteberščice ob Cerkniškem jezeru, v manjši meri pa v izvir Žerovniščice in izvir v Podložu. Sledila nismo zaznali v Studencu v Ložu in v izviru Zlatovec pri Goričicah. Med točko injiciranja in izviri smo opazovali 3 jame in največje koncentracije sledila zabeležili v Mrzli jami pri Bločicah, precej manjše pa v Križni jami in Križni jami 2. To kaže, da ob srednjem vodostaju v vodonosniku vode Farovščice ne tečejo neposredno skozi rove Križnih jam, temveč mimo ali pod njimi. Ker se je sledilo v Križni jami pojavilo šele po padavinah, so lahko vodne poti ob višjem vodostaju značilno drugačne. Sledilni poskus je nakazal tudi določene značilnosti podzemnega toka skozi dolomit ter značilnosti kombiniranega alogeno-avtogenega napajanja vodonosnika.

Ključne besede: sledilni poskus, dolomitni vodonosnik, tveganje za onesnaženje, Križna jama, Slovenija.

\footnotetext{
${ }^{1}$ Karst Research Institute ZRC SAZU, Titov trg 2, SI-6230 Postojna, Slovenija, e-mail: kogovsek@zrc-sazu.si, mitja.prelovsek@zrc-sazu.si,petric@zrc-sazu.si.
}

Received/Prejeto: . 25.9.2008 


\section{INTRODUCTION}

Križna jama is a well known cave due to its high biodiversity ( 45 defined troglobionts up to $2000-4^{\text {th }}$ place in the world; Culver \& Sket 2000) and numerous findings of Ursus spelaeus bones. At the end of 19th century F. von Hochstetter excavated more than 2.000 Ursus spelaeus bones but a still unknown quantity lies untouched in the cave. But the importance of the cave is not recognized just in these two values. Due to its length (Križna jama with its hydrological and geomorphological continuation Križna jama 2 has a total length of passages almost $10 \mathrm{~km}$ ) the cave gives us excellent insight into the water course between the occasionally flooded Bloke plateau and Cerknica polje. The main hydrochemical and hydrogeomorphological characteristic of this underground water flow is oversaturated water, which causes a vast deposition of flowstone from the main stream. Since the deposition is higher at the locations with fast flowing water, 47 underground lakes were formed behind rimstone dams in the Holocene. Because of its natural richness, Križna jama takes important place in the list of 21 Slovene tourist caves.

Direct and indirect influences of human activities are the biggest hazard for both caves. Recognizable damage of cave floors and flowstone dams has been made by cavers and visitors that enter the cave, but even if we close the cave for visiting (this is the case of Križna jama 2), severe damage can be caused indirectly through polluted water. The latter can significantly influence the flowstone deposition process since the deposition is controlled by the presence of different non-carbonate anions $\left(\mathrm{PO}_{4}^{3-}\right.$, $\mathrm{NO}_{3}^{-}, \mathrm{Cl}^{-}$; Dreybrodt 1988, Dreybrodt 2000). If the concentration of these and similar ions would be too high in the underground water, flowstone deposition process could be slowed down or even inverted to corrosion and rimstone dams could be much more endangered. An additional threat could be a planned water treatment plant at the Bloke plateau from which waste waters are directed into a nearby ponor. Although water treatment plant will include only primary and secondary treatment and not tertiary treatment, outflow is relatively low $(0.46$ $\mathrm{l} / \mathrm{s}$ at the beginning and $0.76 \mathrm{l} / \mathrm{s}$ at full operation). Such quantity could hardly have any influence to Križna jama at middle and high water level but can change the cave environment severely at low water levels, when the input from the water treatment plant could be the only source of water for Križna jama. To plan proper protection measures we should know more about the underground water flow directions and dynamics in the area, therefore a tracer test with the injection into this ponor was carried out in 2007. The aquifer between Bloke plateau and Cerknica polje is recharged by autogenic and allogenic input. The outflow from the system can be observed in different springs and in the caves. Therefore obtained results have also broader importance in understanding the underground water flow in complex karst aquifers.

\section{HYDROGEOLOGICAL CHARACTERISTICS}

The aquifer between Bloke plateau and Cerknica polje (Fig. 1) is composed of 4 lithostratigraphical units (Buser et al. 1967, Buser 1968): Upper Triassic dolomite $\left(\mathrm{T}_{3}{ }^{2+3}\right)$, Lower Jurassic dolomite $\left(\mathrm{J}_{1}\right)$, Lower-Middle Jurassic limestone with thin lenses of dolomite $\left(\mathrm{J}_{1,2}\right)$ and Upper Jurassic dolomites $\left(\mathrm{J}_{3}\right)$. All the units are generally inclined for 20 to 40 degrees towards southwest. Without any significant tectonic displacement, they show a quite undisturbed chronostratigraphical sequence from the oldest rocks at the northeast (Bloke plateau) to the youngest at southwest (Cerknica polje). Lower-Middle Jurassic limestone is well karstified and shows a high degree of secondary porosity. The majority of Križna jama and Križna jama 2 passages are formed in this type of limestone. Permeability of Triassic and Lower Jurassic dolomites is unclear. They are functioning as semi-permeable layers at fluvio-karstic Bloke plateau but $420 \mathrm{~m}$ of upstream water passages in Križna jama are developed in Lower Jurassic dolomite as well. Although the contact between limestone and dolomite is easily recognized at the cave walls, it is not importantly expressed in the passage morphology. In Križna jama, differences between limestone and dolomite are slightly reflected in passage size but not in water gradient (Prelovšek et al. 2008). We should stress also that the Bloščica and Farovščica streams on the Bloke plateau sink already in Triassic dolomite approximately $1,200 \mathrm{~m}$ north-eastern from the contact with Jurrasic limestone.

The aquifer is fed by two superficial streams and primary infiltration of precipitation. The comparison of discharges (measured in the period 1972-1975; Gospodarič \& Habič 1976) of superficial streams from Bloke plateau $\left(0.5 \mathrm{~m}^{3} / \mathrm{s}\right.$ on average $)$ and springs at Cerknica polje $\left(1.51 \mathrm{~m}^{3} / \mathrm{s}\right.$ on average) gives us the rough estimation of autogenic recharge $-66 \%$. 


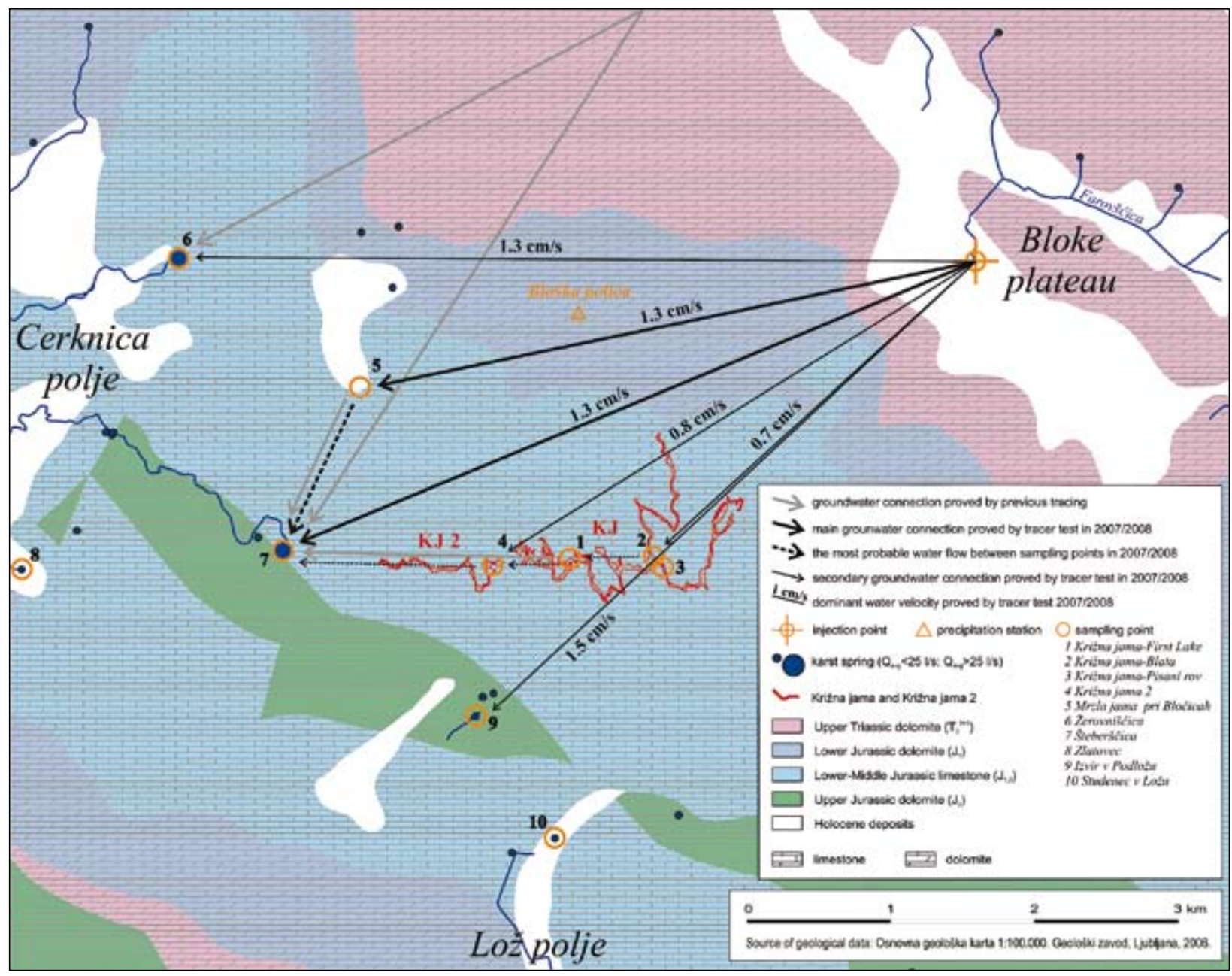

Fig. 1: Hydrogeological map of the aquifer between Bloke plateau and Cerknica polje with underground water connections (already known and proved by tracing in December 2007).

Position of the ponors at Bloke plateau at the altitude approximately $720 \mathrm{~m}$ and the springs on the eastern side of Cerknica polje at the altitude approximately $560 \mathrm{~m}$ indicates a general underground water gradient in NE-SW direction. This was confirmed by a dye tracing experiment in 1939 when the water connection between the Bloščica ponor on the upper side and the Žerovniščica and Šteberščica springs on the lower side was proved. Underground water flow to Lož polje and SE part of Cerknica polje is thought to be limited due to crushed rocks along the Idrija strike slip fault which acts as a barrier and due to a lower hydraulic gradient. On the northwestern part of the aquifer Upper Triassic dolomites with significantly lower hydraulic gradient probably present a barrier between superficial Cerkniščica stream and observed aquifer.

Several accesses to underground water level between Bloke plateau and Cerknica polje offer relatively reliable computation of hydraulic gradients in this area. Such ap- proach can be deceptive in karst regions but it should at least suggest the general direction of water flow. Fig. 2 indicates general water flow from Bloščica and Farovščica ponors toward Šteberščica and Žerovniščica springs. In the NE part of the aquifer the hydraulic gradient is higher probably because of the lower permeability of dolomite. The equipotential lines are more parallel which is a result of a lack of data on piezometric water levels in this area. In the SW part of the aquifer the hydraulic gradient seems to be lower due to a well permeable Jurassic limestone. The hydraulic gradient in Križna jama is especially low since the cave is nearly horizontal and dimensions of water passages usually exceed $5 \mathrm{~m}$. In the $\mathrm{SW}$ part of the aquifer we can also observe divergence of water flow toward Žerovniščica and Šteberščica springs.

Križna jama lies exactly in the middle between Bloke plateau and Cerknica polje at elevation about $605 \mathrm{~m}$ a.s.l. In the upstream part it is composed of two main water passages, Pisani rov (eng. Coloured Passage) $(\sim 1,290$ 


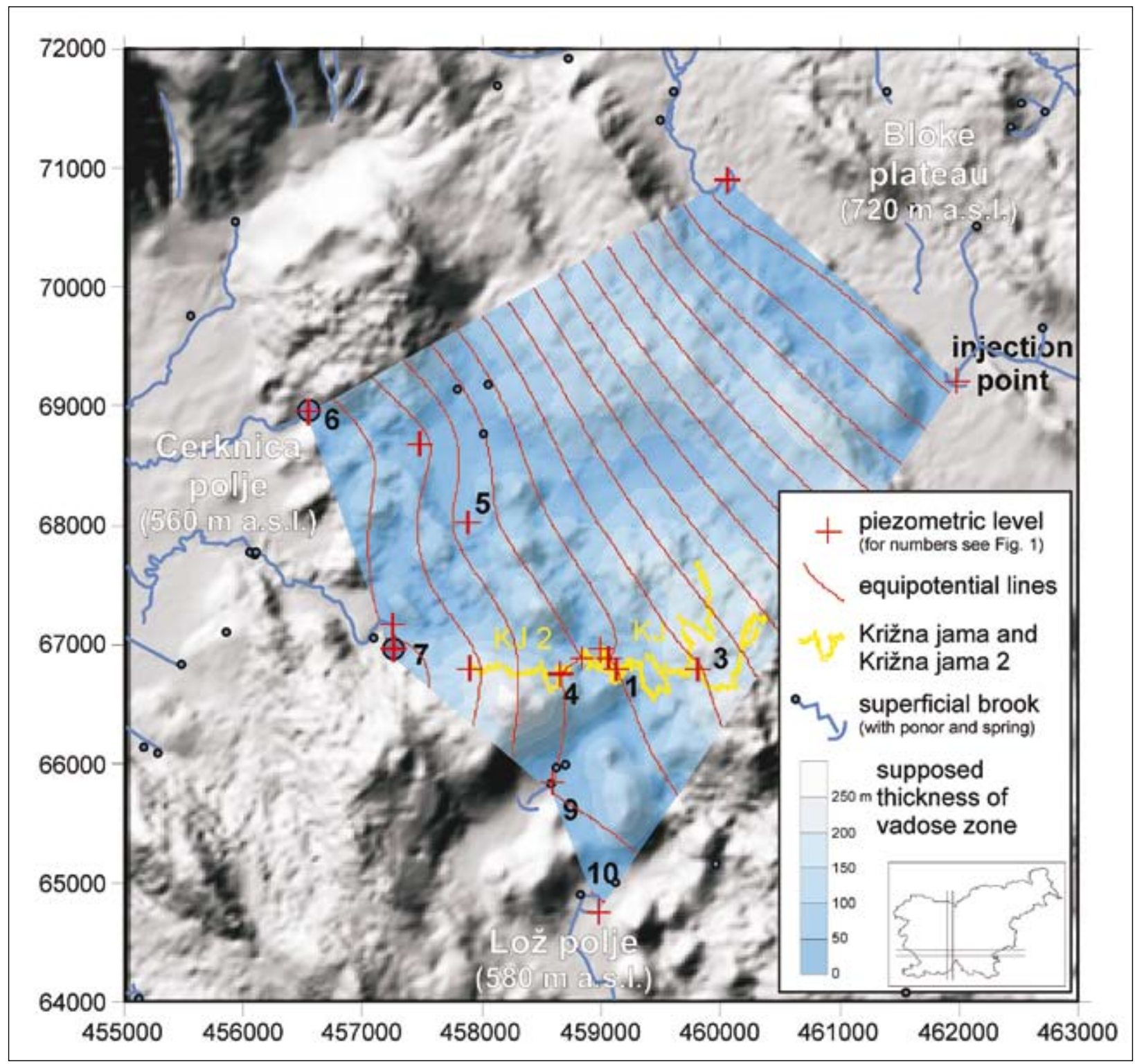

Fig. 2: Probable underground water level computed from the piezometric levels at 17 locations between Bloke plateau, Cerknica polje and Lož polje (source of DEM: IAPŠ ZRC SAZU).

m long passage) and Blatni rov (eng. Muddy Passage) ( 1,670 $\mathrm{m}$ long passage), that join together at breakdown Kalvarija (eng. Calvary; Fig. 3). Uniform water flow continues through Jezerski rov (eng. Lake passage) $(\sim 1,180$ $\mathrm{m}$ long passage) towards 1 . jezero (eng. First Lake), beneath which the underground flow becomes pressurized. Several tributaries were recognized along all three main passages (Prelovsek et al. 2008), among which the most important seems to be tributary from V-rov (eng. $\mathrm{V}$-passage) since its reaction to precipitation is fast and contributes important part of uniform discharge at 1 . jezero in the first part of water pulse. Due to its underground water flow Križna jama was thought for more than 70 years that it is actually the underground water flow of Farovščica and Bloščica streams from Bloke plateau. Thinking about two water courses in Križna jama, which combine at Kalvarija, suited very well with 2 surface streams from Bloke plateau, which would be combined in the cave. But such thinking was never proved by any tracer test. The only proof of the connection with the cave were findings of polystyrene in Križna jama, which were washed underground at Farovščica highflow ponors, and allochtonous sediment in Križna jama, which definitely originates from northern Bloke plateau (Gospodarič 1974). Contrary to these "proofs" are highly oversaturated water and low annual water temperature 


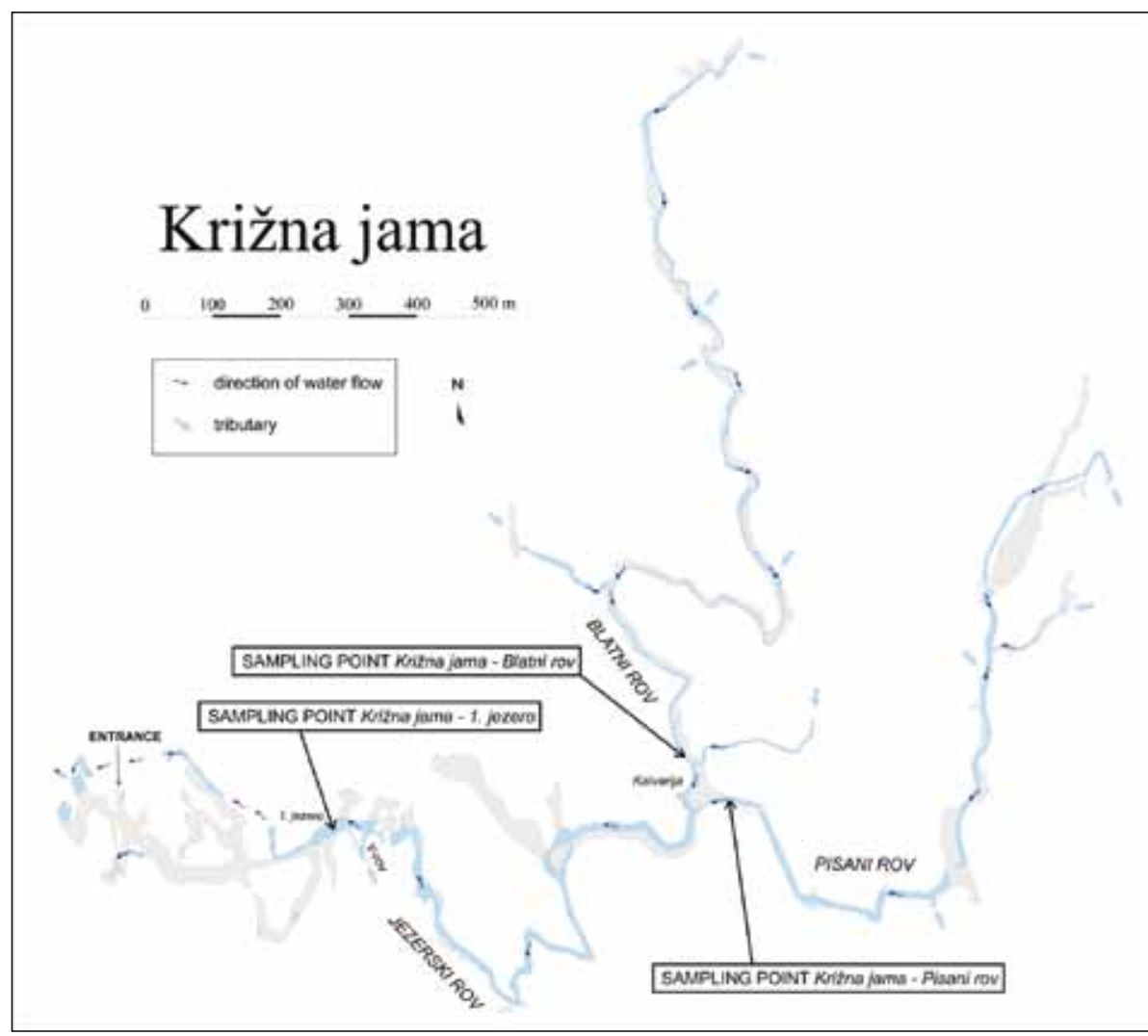

Fig. 3: Plan of Križna jama.

amplitude (less than $1^{\circ} \mathrm{C}$ ) in Križna jama, which should be a result of fracture flow through epikarst and vadose zone. Hydraulic gradients represented on Fig. 2 show that underground water flow of Farovščica is the most probable toward passage Blatni rov in Križna jama. The directions of water flow downward from Križna jama are not problematic since the tracer test proved the connection between Križna jama and Šteberščica in 1965 (Novak 1966, 1969, 1990). Access to Križna jama 2 was not pos- sible until 1991 so we do not know if the dye from Križna jama appeared also in Križna jama 2. But since the chemistry and quantity of water are very similar and the distance between caves is short $(242 \mathrm{~m})$, we suppose that water course in Križna jama continues through Križna jama 2 to Šteberščica spring. Since we know that the water temperature in Križna jama 2 slightly deviates from the water temperature in Križna jama (for about $+0.2{ }^{\circ} \mathrm{C}$ in summer and $-0.2^{\circ} \mathrm{C}$ in winter) we should expect a minor tributary between the two caves.

Area above Križna jama is forested and therefore present minor risk for pollution. Bigger problem is at Bloke plateau where about 1,650 inhabitants live. In central settlements some chemical and metal industry was established in the 1960s. All these activities together with stockbreeding represent a risk for contamination if the sewage water is concentrated in sewage system and (not properly cleaned) directly injected to underground aquifer. Vulnerability is especially high in Križna jama and Križna jama 2, where high biodiversity and growing rimstone dams could be severely endangered if the quantity of partly purified water would be too high.

\section{TRACER TEST IN DECEMBER 2007}

To understand better the characteristics of groundwater flow between the Bloke plateau and the lower lying karst poljes in general and especially to assess the possible impacts of the water treatment plant at the plateau on the Križna jama a tracer test was carried out in December 2007. A fluorescent tracer uranine was injected in the ponor of the Farovščica stream, through which also the outflow from the water treatment plant is drained. Sampling was organised in three caves and seven springs at the foothills of the Bloke plateau.

\section{PHYSICO-CHEMICAL ANALYSIS OF WATERS IN THE BROADER AREA}

Before tracing, the characteristics of springs in the broader area were compared based on the basic physico-chemical analysis (Tab. 1). The aim was to infer the origin of water and to check some parameters of water quality. Samples were taken at those locations within the karst water system in which,-- based on the known hydrogeological conditions and results of previous stud- 
ies (Kogovšek 1998), the occurrence of tracer from the Farovščica ponor can be expected.

The samples of water were collected on $3^{\text {rd }}$ and $4^{\text {th }}$ December 2007 during low waters and decreasing discharge. Additionally, samples at Izvir v Podložu and Studenec v Ložu springs were taken on $11^{\text {th }}$ December 2007 at low waters. The highest values of nitrates and o-phosphates in Studenec v Ložu indicate the influence of the nearby settlement. The lowest values were measured in Zlatovec, and slightly higher in Žerovniščica, Mrzla jama and Šteberščica. For the latter two the values were very similar, which indicates the connection between both springs. In all three measurement points in Križna jama the concentrations of o-phosphates were on the detection limit, only nitrates were slightly increased (Tab. 1). staff gauge. For all three sampling points the discharges were calculated from measured water levels and discharge curves (Figs. 8-10).

After a relatively dry period in October and the first part of November 2007 a smaller amount of rain fell on $25^{\text {th }}$ November and $3^{\text {rd }}$ December. At the time of injection water levels were medium to low. The Farovščica stream was sinking approximately $40 \mathrm{~m}$ ahead of the ponor. Then after the injection approximately $28 \mathrm{~mm}$ of rain in the period from $7^{\text {th }}$ to $11^{\text {th }}$ December resulted in an increase of discharge and transfer of tracer. Additional precipitation was detected in the first half of January 2008 and in the beginning of the next month with $14 \mathrm{~mm}$ on 3 rd February and $20 \mathrm{~mm}$ on $5^{\text {th }}$ February 2008 (Fig. 4). It was partly in the form of snow, but the snow cover melted very fast.

Table 1: Results of physico-chemical analysis (SEC-conductivity, Ca+Mg - total hardness).

\begin{tabular}{|l|r|r|r|r|r|r|r|r|r|}
\hline & $\boldsymbol{T}$ & $\boldsymbol{S E C}$ & $\boldsymbol{p H}$ & $\mathbf{C a}+\mathbf{M g}$ & $\mathbf{C a}$ & $\boldsymbol{M g}$ & $\boldsymbol{C a} / \mathbf{M g}$ & Nitrates & Phosphates \\
\cline { 2 - 10 } & $\mathrm{oC}$ & $\mu \mathrm{S} / \mathrm{cm}$ & & & $\mathrm{meq} / \mathrm{l}$ & & & $\mathrm{mg} / \mathrm{l}$ & $\mathrm{mg} / \mathrm{l}$ \\
\hline Žerovniščica & 9.8 & 517 & 7.63 & 5.83 & 3.57 & 2.26 & 1.6 & 3.2 & 0.04 \\
\hline Šteberščica & 8.3 & 502 & 8.01 & 5.59 & 3.53 & 2.06 & 1.7 & 4.3 & 0.05 \\
\hline Zlatovec & 8.8 & 505 & 7.28 & 5.58 & 5.03 & 0.55 & 9.1 & 2.7 & $<0.01$ \\
\hline Mrzla jama & 7.8 & 520 & 7.80 & 5.33 & 3.41 & 1.92 & 1.8 & 4.5 & 0.05 \\
\hline Križna jama - 1. jezero & 8.4 & 470 & 8.38 & 5.29 & 3.65 & 1.64 & 2.2 & 4.2 & $<0.01$ \\
\hline Križna jama - Blatni rov & & & & 5.42 & 3.87 & 1.55 & 2.5 & 4.9 & 0.01 \\
\hline Križna jama - Pisani rov & & & & 5.28 & 3.59 & 1.69 & 2.1 & 4.5 & $<0.01$ \\
\hline Izvir v Podložu & 8.6 & 520 & 7.26 & 5.98 & 4.50 & 1.48 & 3.0 & 2.8 & $<0.01$ \\
\hline Studenec v Ložu & 9.2 & 508 & 7.25 & 5.24 & 5.00 & 0.24 & 20.8 & 6.7 & 0.32 \\
\hline
\end{tabular}

\section{PRECIPITATION AND HYDROLOGICAL} CONDITIONS IN THE TIME OF TRACING

In the time of tracing, precipitation on the Bloke plateau was measured at 15-minutes intervals with the rain-gauge Eijkelkamp e+ installed at Bloška polica on $4^{\text {th }}$ December 2007. Discharges were observed in the Šteberščica and Žerovniščica springs and in the 1 . jezero in Križna jama in order to assess the recovery of tracer. At these locations water levels were measured in parallel with sampling. Based on occasional measurements of discharges with current meter OTT C-20 in Šteberščica and Žerovniščica and with salt-dilution method (Käss 1998) in 1. jezero in Križna jama the discharge curves were defined. The water level of the Šteberščica spring was measured at the existing staff gauge below the bridge of the road Žerovnica-Lipsenj, and of the Žerovniščica spring approximately $20 \mathrm{~m}$ downstream of the spring near a small bridge. The water level of the 1. jezero in Križna jama was measured at the existing
Precipitation in the first week after the injection resulted in an increase of discharges. In the Šteberščica spring the first peak with the discharge $2.3 \mathrm{~m}^{3} / \mathrm{s}$ was reached on $9^{\text {th }}$ December 2007 in the morning. Three smaller peaks were observed in January 2008, and within the period of sampling the maximum discharge $3.9 \mathrm{~m}^{3} / \mathrm{s}$ was measured on $5^{\text {th }}$ February 2008. The lowest observed discharges were below $0.15 \mathrm{~m}^{3} / \mathrm{s}$. Characteristic discharges of this spring, which are available only for the period 1972-1975, range between $0.01 \mathrm{~m}^{3} / \mathrm{s}$ and $16 \mathrm{~m}^{3} / \mathrm{s}$, and the mean discharge is $1.3 \mathrm{~m}^{3} / \mathrm{s}$ (Gospodarič \& Habič 1976).

The shape of the hydrograph for the Žerovniščica spring is very similar with the first peak on $8^{\text {th }}$ December 2007 in the evening with $0.66 \mathrm{~m}^{3} / \mathrm{s}$, and the highest peak on $5^{\text {th }}$ February 2008 with almost $1 \mathrm{~m}^{3} / \mathrm{s}$. The lowest observed discharges were below $0.18 \mathrm{~m}^{3} / \mathrm{s}$. In the period 1972-1975 the minimum discharge was $0.01 \mathrm{~m}^{3} /$ $\mathrm{s}$ and the maximum $7.6 \mathrm{~m}^{3} / \mathrm{s}$. The mean discharge was $0.21 \mathrm{~m}^{3} / \mathrm{s}$ (Gospodarič \& Habič 1976). 


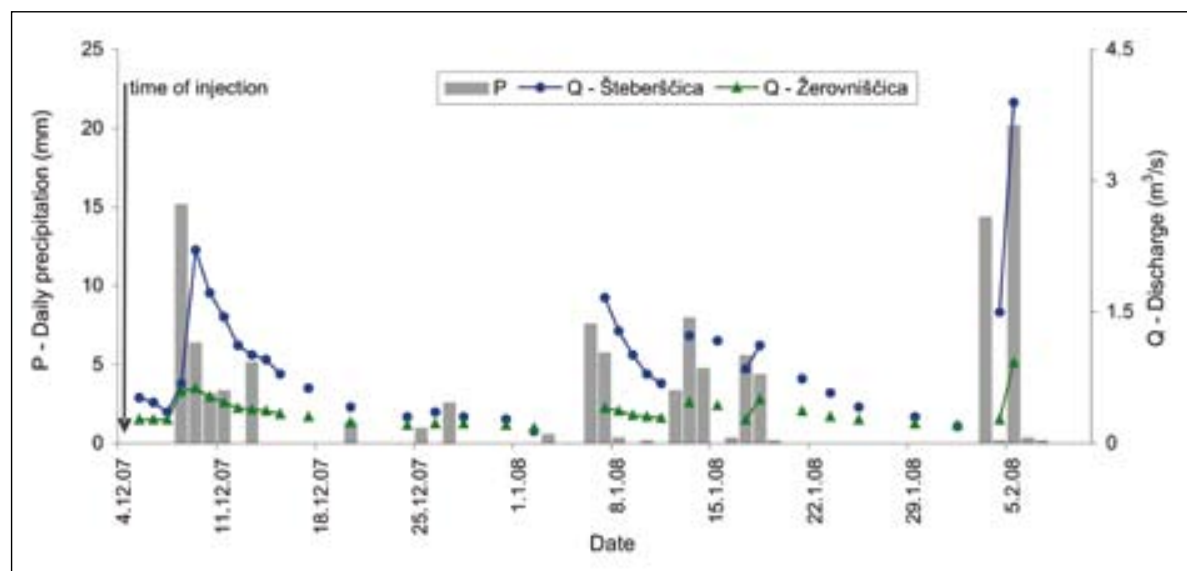

Fig. 4: Measured daily precipitation at Bloška polica and discharges of Šteberščica and Žerovniščica springs in the time of tracer test.

For the discharges in the 1. jezero in Križna jama no previous data are available. Our measurements ended on $18^{\text {th }}$ January 2008, so the peak in the beginning of February 2008 was not observed. The maximum measured discharge was $0.233 \mathrm{~m}^{3} / \mathrm{s}$ on 9th December 2007 in the morning. After short recession a small increase of discharge was detected in the evening of the same day, then discharges were decreasing again until the beginning of January 2008. The minimum discharges were below $0.020 \mathrm{~m}^{3} / \mathrm{s}$.

\section{INJECTION OF TRACER}

A walled-in ponor of the Farovšcica stream, into which the outflow from the water treatment plant is drained also, was chosen as the injection point. In the time of injection only water from the water treatment plant was sinking there (several $\mathrm{dl} / \mathrm{s}$ ) because the Farovščica stream was sinking several meters upstream of the ponor. A solution of $226 \mathrm{~g}$ of uranine was injected on 4 th December 2007 at 12:30 a.m. and washed off with approximately $0.2 \mathrm{~m}^{3}$ of water taken from the Farovščica stream. Because sinking of water through the sediment at the bottom of the ponor was very slow the tracer was injected into a fissure in the wall of the walled-in ponor (Fig. 5). As a small amount of tracer flowed into the stagnant water at the ponor, the ponor was covered for 19 hours with black plastic sheet in order to prevent decay of tracer due to sun light. Within this time the tracer was completely washed out through the ponor.

\section{SAMPLING AND ANALYSIS OF WATER SAMPLES}

The sampling points were selected based on the physico-chemical characteristics of water in the broader area (especially the $\mathrm{Ca} / \mathrm{Mg}$ ratio), and on results of previous tracer tests and hydrogeological researches in the area between the Bloke plateau, and Lož and Cerknica poljes. Higher Ca/Mg ratios in the Zlatovec and Studenec v Ložu springs indicate that these springs are mainly recharged from limestone, therefore we did not expect the occurrence of uranine in them. Coordinates (state system in

Table 2: Coordinates of the injection and sampling points $(X, Y, Z)$, and distance $(\Delta D)$, altitude difference $(\Delta H)$ and hydraulic gradient (i) between the Farovščica ponor and the sampling points.

\begin{tabular}{|l|r|r|r|r|r|r|}
\hline Location & $\boldsymbol{X}$ & $\boldsymbol{Y}$ & $\boldsymbol{Z}$ & $\boldsymbol{\Delta D}(\boldsymbol{m})$ & $\boldsymbol{\Delta H}(\boldsymbol{m})$ & \multicolumn{2}{|c|}{$\boldsymbol{i}(\%)$} \\
\hline Farovščica ponor (injection point) & 462046 & 69345 & 717 & \multicolumn{2}{|c|}{ (from the Farovščica ponor) } \\
\hline Križna jama - Blatni rov & 459747 & 66966 & 618 & 3308 & 99 & 2.99 \\
\hline Križna jama - Pisani rov & 459794 & 66900 & 619 & 3324 & 98 & 2.95 \\
\hline Križna jama - 1. jezero & 459215 & 66845 & 616 & 3777 & 101 & 2.67 \\
\hline Križna jama 2 & 458644 & 66734 & 600 & 4288 & 117 & 2.73 \\
\hline Mrzla jama & 457900 & 68020 & 595 & 4353 & 122 & 2.80 \\
\hline Žerovniščica & 456525 & 68938 & 564 & 5536 & 153 & 2.76 \\
\hline Šteberščica & 457240 & 66900 & 563 & 5392 & 154 & 2.86 \\
\hline Zlatovec & 455246 & 66007 & 553 & 7575 & 164 & 2.16 \\
\hline Izvir v Podložu & 458589 & 65755 & 600 & 4984 & 117 & 2.35 \\
\hline Studenec v Ložu & 458973 & 64766 & 588 & 5515 & 129 & 2.34 \\
\hline
\end{tabular}




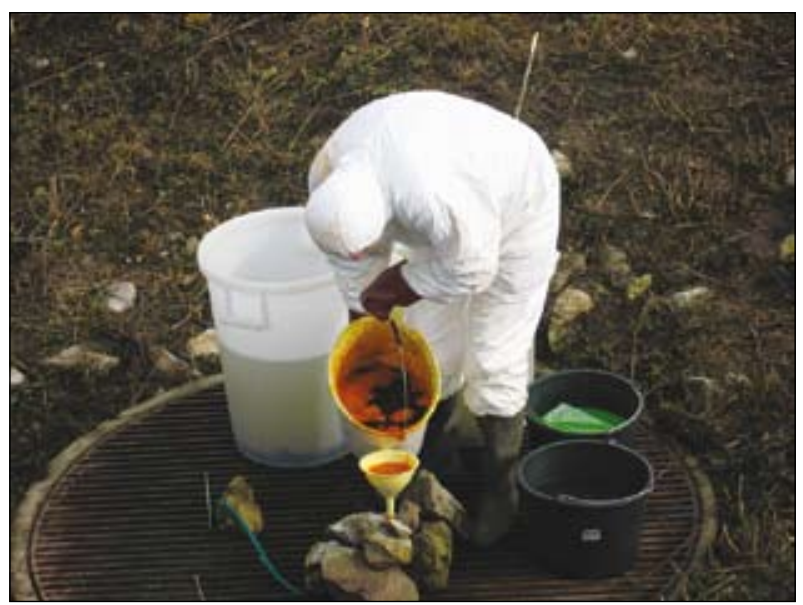

Fig. 5: Injection of uranine through the pipe into the fissure in the lateral wall of the ponor (foto: Janja Kogovšek).

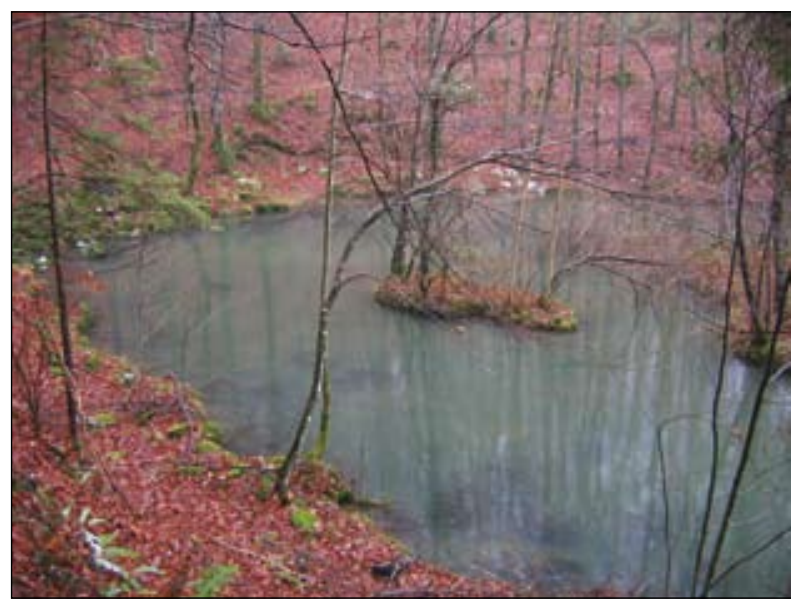

Fig. 6: Sampling point at the Šteberščica spring (foto: Mitja Prelovšek).

Gauss-Krüger projection) of the injection and sampling points, as well as the linear distances between them are presented in Table 2.

The sampling was manual. The most frequent (up to 3 times per day) was organised in the 1 . jezero in Križna jama. The duration of sampling was the longest in the Šteberščica, Žerovniščica and Izvir v Podložu springs and in the 1. jezero in Križna jama. Frequency of sampling was defined based on the importance of the individual point and the probability of the occurrence of tracer (up to 2 times per day).

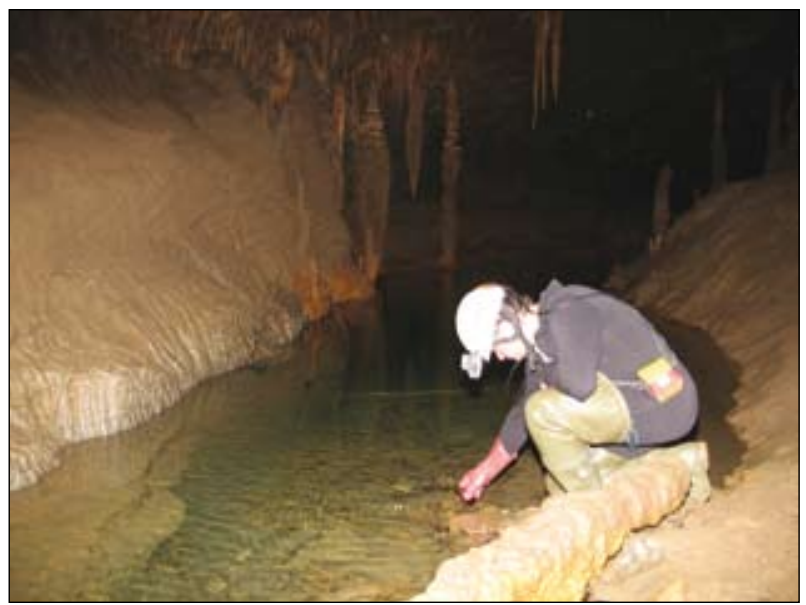

Fig. 7: The Križna jama, sampling in the Blatni rov (foto: Mitja Prelovšek).

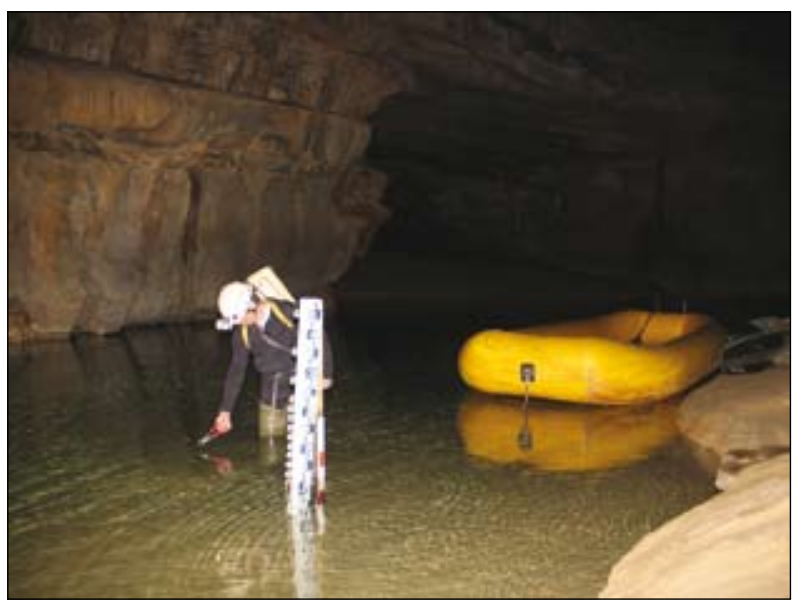

Fig. 8: Sampling in the 1. jezero in Križna jama (foto: Mitja Prelovšek).

Fluorescence was measured in laboratory of the Karst Research Institute by a Luminescence Spectrometer LS 30, Perkin Elmer $\left(\mathrm{E}_{\mathrm{ex}}=491 \mathrm{~nm}, \mathrm{E}_{\mathrm{em}}=512 \mathrm{~nm}, \mathrm{~F}=1\right)$ on original samples. Concentrations of uranine are expressed in $\mathrm{ppb}\left(\mu \mathrm{g} / \mathrm{l}\right.$ or $\left.\mathrm{mg} / \mathrm{m}^{3}\right)$. 


\section{RESULTS OF TRACING}

\section{DIRECTIONS AND VELOCITIES OF UNDERGROUND WATER FLOW}

Injected tracer was detected in the water flow in $\mathrm{Mr}$ zla jama, in the Šteberščica, Žerovniščica and Izvir v Podložu springs, in the Blatni rov in Križna jama and in the Križna jama 2. It did not occur in the Zlatovec spring and in the Pisani rov in Križna jama. In the Studenec v Ložu spring tracer concentrations were around the detection limit.

Uranine was first detected in Mrzla jama approximately 70 hours after the injection $\left(7^{\text {th }}\right.$ December 2007 at 12:40 a.m.). The maximum concentration of $1.16 \mathrm{ppb}$ was measured 25 hours later. In Šteberščica and Žerovniščica the first appearance of tracer was observed 102 hours after the injection ( $8^{\text {th }}$ December 2007 at 7 p.m.). In Šteberščica the maximum concentration of $0.5 \mathrm{ppb}$ was measured after additional 11 hours $\left(9^{\text {th }}\right.$ December 2007 at 6 a.m.), and in Žerovniščica the concentration of $0.32 \mathrm{ppb}$ on $9^{\text {th }}$ December 2007 at 11 a.m. Significantly lower were concentrations of uranine in Izvir v Podložu. The highest concentration of $0.05 \mathrm{ppb}$ was measured at the first appearance 94 hours after the injection.

First precipitation after the injection was measured in the night between $7^{\text {th }}$ and $8^{\text {th }}$ December 2007 (15.2 $\mathrm{mm})$, then in the next three days fell an additional 13 $\mathrm{mm}$ of rain. It resulted in an increase of discharge. In Mrzla jama it reached a maximum on $9^{\text {th }}$ December 2007 in the morning. The concentration of tracer was the highest even before in the time of the rising limb of the hydrograph ( $8^{\text {th }}$ December in the morning), afterwards it was slowly decreasing. We can infer that the rain did not trigger this first occurrence of tracer (Fig. 9), but only the following ones.

But rain influenced the occurrence of tracer at other sampling points. In Šteberščica (Fig. 9) there was a short lag between the first increase of discharge and the first occurrence of tracer. Then the increase of concentration was very fast and it reached the maximum concentration on $9^{\text {th }}$ December 2007 at 6 a.m. Discharge was the highest a few hours later, when the concentration decreased rapidly. Afterwards the decrease was slower and reached the detection limit on $28^{\text {th }}$ December 2007. Additional precipitation in January 2008 resulted in increased discharges and further transport of the tracer, which was detected only in the time of discharge decrease.

Slightly increased con-

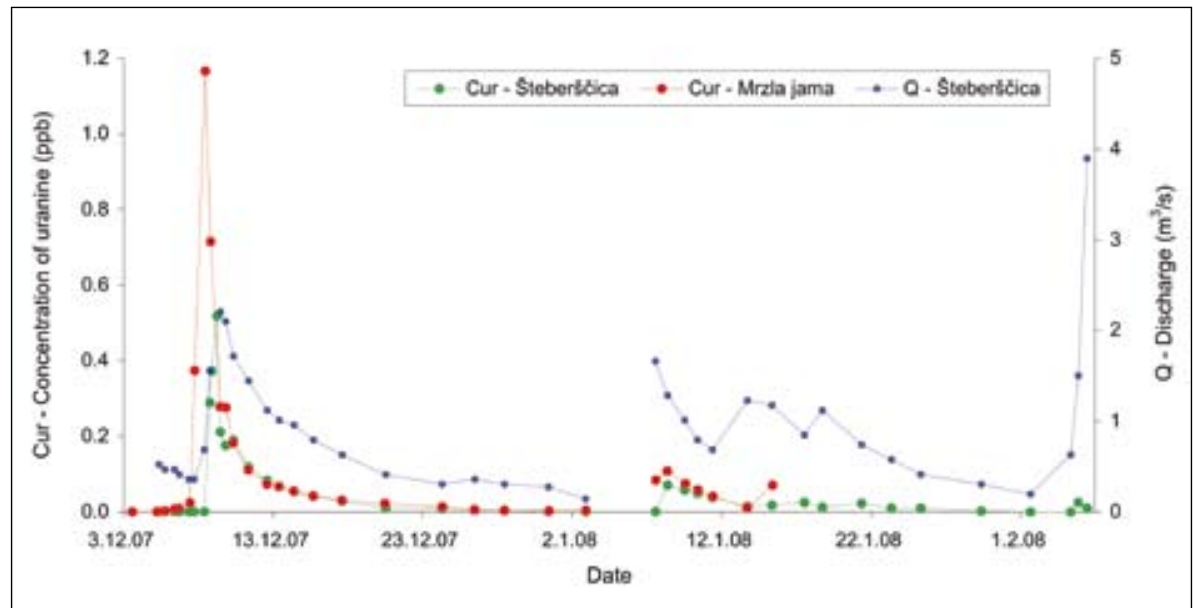

Fig. 9: Uranine breakthrough curves at Mrzla jama and Šteberščica.

A fast increase of tracer concentrations in Mrzla jama, Šteberščica and Žerovniščica was followed first by a fast decrease, and then with slower recession towards the detection limit, which was reached in Mrzla jama and Šteberščica on $28^{\text {th }}$ December 2007 , and in Žerovniščica already on $20^{\text {th }}$ December 2007. In Izvir v Podložu the concentration was below this limit already on $12^{\text {th }}$ December, but has increased again later. centrations of uranine in Šteberščica and Izvir v Podložu and in the 1 . jezero in Križna jama were again detected in the beginning of February 2008 as a result of snow melting on Bloke plateau, when the springs reached the maximum discharges in the time of tracing.

The occurrence of tracer in the Žerovniščica spring (Fig. 10) was simultaneous with the peak discharge on $8^{\text {th }}$ December 2007 at 7 p.m. The maximum concentration of uranine was measured only few hours later, when the discharge was decreasing. We can infer that the recharge of the spring from other parts of the catchment is significant.

After next precipitation the tracer was detected again, but only in low concentrations and when the discharge decreased, which indicates strong dilution effects.

In the Izvir v Podložu spring low concentrations of tracer were detected in shorter period in the time of the peaks in Šteberščica and Žerovniščica, as well as later following individual precipitation events (Fig. 10). 


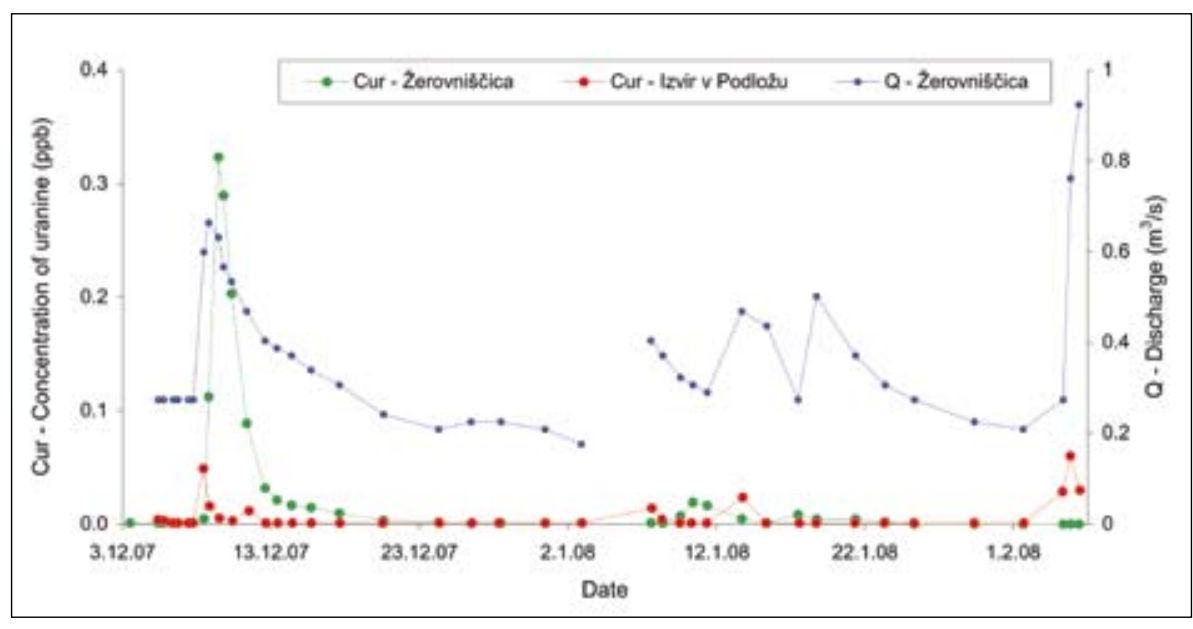

Fig. 10: Uranine breakthrough curve at Žerovniščica and Izvir v Podložu.

\section{THE KRIŽNA JAMA}

In the Križna jama the tracer was first detected on $9^{\text {th }}$ December 2007 at 6 a.m. in Blatni rov. The concentration increased fast until noon, then temporarily stagnated and further increased to the maximum value of $0.14 \mathrm{ppb}$ on $10^{\text {th }}$ December 2007 at 6:40 a.m. (Fig. 11). Regular recession of concentration was observed until $13^{\text {th }}$ December 2007, then the concentration slightly increased again. The main outflow of uranine through the Blatni rov lasted four and a half day. Similar breakthrough curve with approximately 2-times lower concentrations was detected in the 1 . jezero also.

The water stream from the Pisani rov flows into the stream in Blatni rov several tens of metres downstream the sampling point. During high waters a strong inflow from the V-rov (eng. V-Passage) joins this stream just in front of the 1. jezero. The reaction of this inflow on precipitation events is significantly faster than of the flow in Blatni rov and Pisani rov. Therefore the increase of discharge in the 1 . jezero was observed 21 hours before the appearance of tracer in Blatni rov and 36 hours before its appearance in 1 . jezero respectively. In Pisani rov only a small peak with tracer concentrations around the detection limit was observed. This could be explained as a washing out of the catchment during increased discharges. Both inflows from the Pisani rov and V-rov re-

curve $\mathrm{C}_{\max }$ detected at time $\mathrm{t}_{\mathrm{dom}}$ ) and maximum apparent flow velocities $\mathrm{v}_{\max }$ (regarding the first appearance of tracer detected at time $t_{\max }$ ) were calculated (Tab. 3). The highest maximum apparent flow velocity $\mathrm{v}_{\max }=1.7 \mathrm{~cm} / \mathrm{s}$ was defined for the connection with Mrzla jama. For the connections with Šteberščica, Žerovniščica and Izvir v Podložu the maximum apparent flow velocities were $1.5 \mathrm{~cm} / \mathrm{s}$. The dominant apparent flow velocities were with $1.3 \mathrm{~m} / \mathrm{s}$ the same for all mentioned springs. sulted in a dilution of uranine flowing along the Blatni rov, which was reflected in smaller tracer concentrations in the 1. jezero.

The actual path from the sampling point in the Blatni rov to the 1 . jezero is $1250 \mathrm{~m}$ long. At discharge $200 \mathrm{l} / \mathrm{s}$ the travel time of tracer was 12 hours (Fig. 11), which gives the actual flow velocity $2.8 \mathrm{~cm} / \mathrm{s}$ and $100 \mathrm{~m} / \mathrm{h}$ respectively. Decreases in tracer concentrations were in the Blatni rov and 1. jezero simultaneous, therefore the main tracer wave in the latter lasted 12 hours less. This 


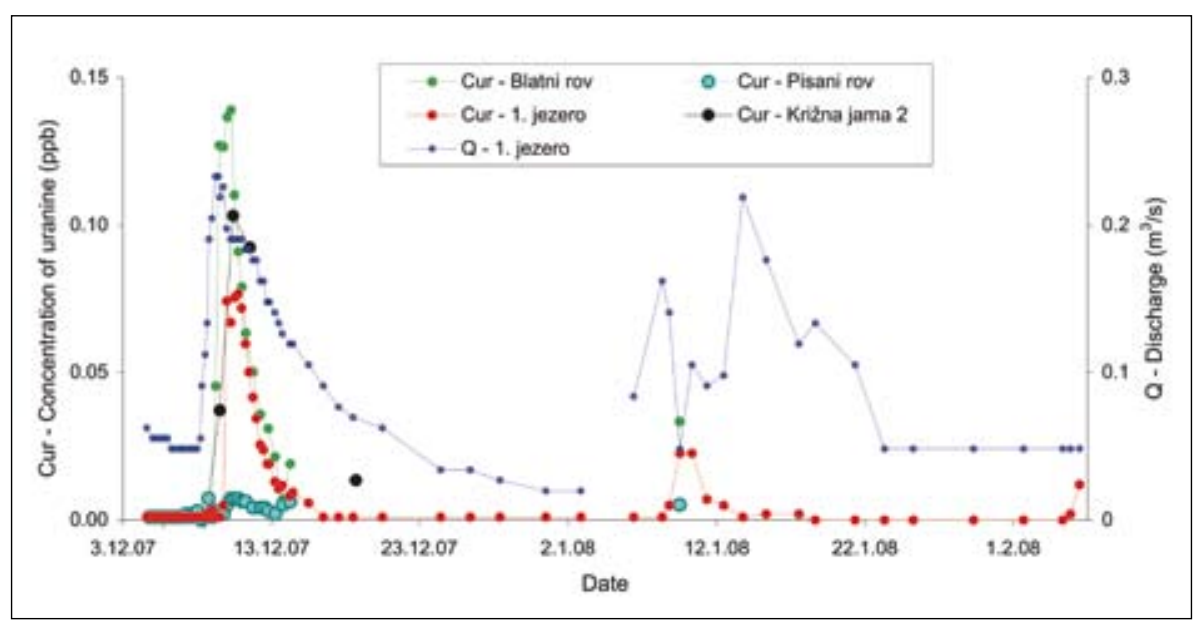

Fig. 11: Breakthrough curves at Križna jama 2 and Blatni rov, Pisani rov and 1. jezero within Križna jama, and discharges measured in the 1. jezero.

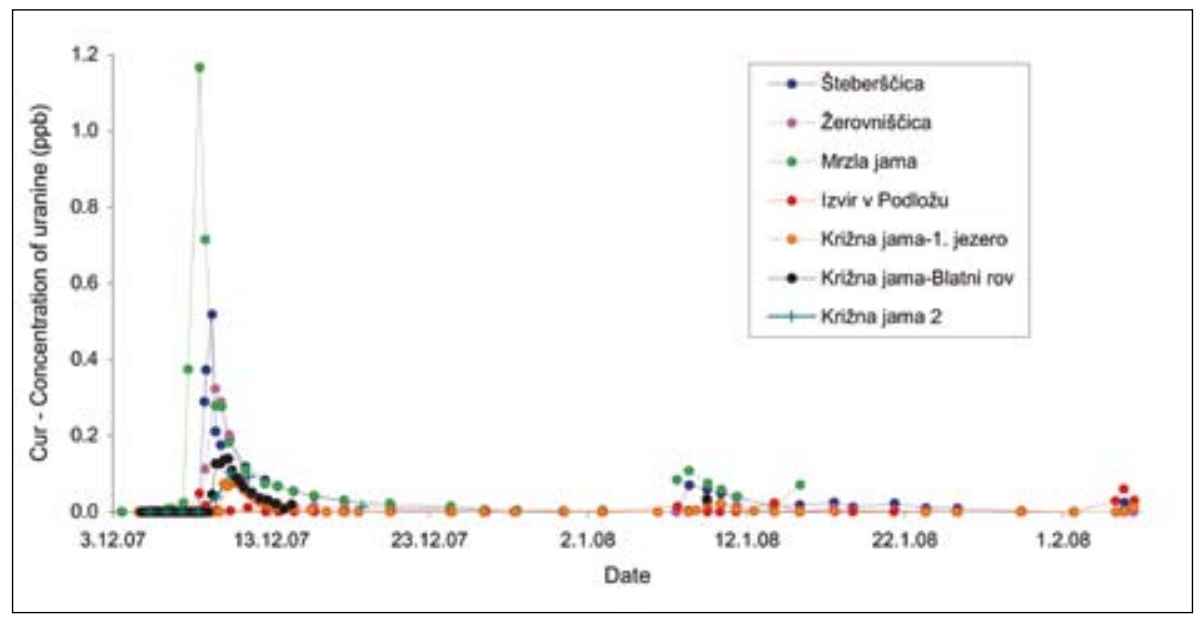

Fig. 12: Breakthrough curves of uranine at the observed springs.
In the 1. jezero the lag of the occurrence of tracer behind the increase of discharge is 36 hours (Fig. 11), which can be partly explained with significantly increased inflow from the V-rov. Only when the discharge started to decrease, the tracer concentrations began to increase (on $9^{\text {th }}$ December 2007 at 6 p.m.). Then the increase of tracer concentrations was fast and reached the value of 0.075 ppb on $10^{\text {th }}$ December 2007 at 0:00. For approximately one day it oscillated around this value and then started to decrease until $16^{\text {th }}$ December 2007 when the detection limit was reached. The next increase was observed after precipitation, in the period of decrease of discharge on $8^{\text {th }}$ January 2008.

\section{RECOVERY OF TRACER}

The largest part of tracer occurred in the Šteberščica spring. As we were not able to measure the discharges in the Mrzla jama it was not possible to assess the recovery of tracer in this cave. But we can

indicates important inflows of water without tracer from the V-rov and Pisani rov, which significantly dilutes the tracer concentration in the 1 . jezero. In the first part of the tracer wave the inflow from the V-rov is more significant and the inflow from the Pisani rov is less important, and in the second part the latter is dominant. Namely, at medium waters the inflow from the V-rov is negligible.

Occasionally the samples in the less accessible Križna jama 2 were taken also. In the samples until $8^{\text {th }}$ December 2007 no tracer was detected, on $9^{\text {th }}$ December 2007 at 12:45 the tracer concentration was $0.035 \mathrm{ppb}$, and after 22 hours the maximum concentration of $0.1 \mathrm{ppb}$ was measured (Fig. 11). Moreover the detection of uranine in the Križna jama 2 previous to its detection in the 1. jezero in Križna jama and its higher concentration indicate a direct inflow of traced water into the Križna jama 2 and into the section between the 1. jezero and Križna jama 2 respectively. infer that the tracer travelled through Mrzla jama into the Šteberščica spring. The most intensive transfer lasted one week and in this time more than a half of injected tracer was detected at this spring (Fig. 12). After precipitation in January 2008 and snow melting in the beginning of February 2008 the tracer concentrations increased again. Until $5^{\text {th }}$ February 2008 approximately $164 \mathrm{~g}$ of uranine was detected at the spring, which amounts to $72.6 \%$ of injected tracer (Fig. 13).

The discharges of Šteberščica were measured downstream from the springs in the riverbed. This part of the stream has some additional inflows which were not sampled. If no tracer appeared in them, the actual share of the recovered tracer could be slightly lower.

At the Žerovniščica spring $34 \mathrm{~g}$ of uranine was recovered, which amount to $15 \%$ of injected tracer (Fig. 13). The largest part was detected in the first tracer wave. 


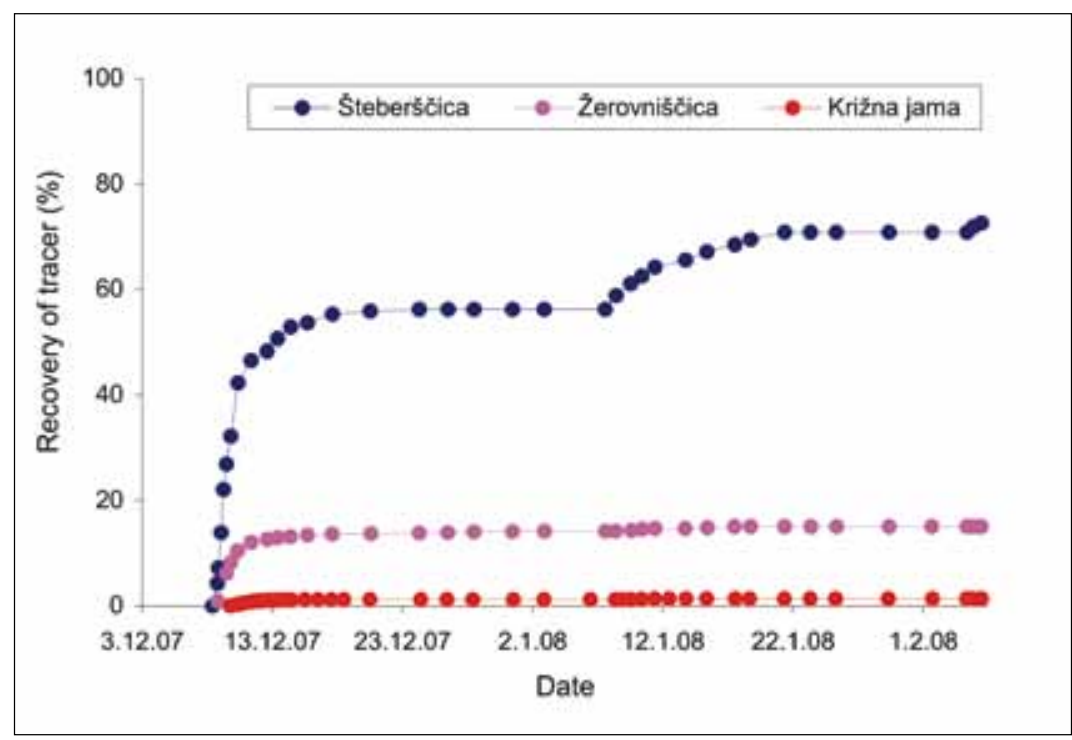

Fig. 13: Recovery of uranine.
The connection with Križna jama was weaker ( $3 \mathrm{~g}$ or $1.3 \%$ ). Again the main outflow was in the first wave, and only small amount was detected in January and February 2008.

The outflow through the Izvir v Podložu was minimal. The assessment of recovery for the Križna jama 2 was not possible, because no discharge data are available. Additionally, only a few samples were taken because the sampling was limited by the Environmental Agency in order to protect the cave. But according to our approximate assessment the amount of recovered tracer could be larger than in the Križna jama. Additional research should be done to confirm this supposition.

\section{CONCLUSIONS}

Uranine injected at Farovščica ponor in December 2007 was detected at 6 sampling locations: water cave Mrzla jama, Šteberščica spring, Žerovniščica spring, passage Blatni rov in Križna jama, Križna jama 2 and Izvir v Podložu spring (Fig. 1). The majority of tracer appeared in Šteberščica (72.6 \%), much less in Žerovniščica (15 \%) and less than $1 \%$ in Izvir v Podložu with dominant apparent flow velocity $1.3 \mathrm{~cm} / \mathrm{s}$. In Križna jama only $1.3 \%$ of injected tracer recovered, and calculated dominant apparent flow velocity was $0.7 \mathrm{~cm} / \mathrm{s}$.

The first appearance and the highest concentration of tracer were detected in Mrzla jama. The first appearance was not influenced by rain, so the maximum $(1.7 \mathrm{~cm} / \mathrm{s})$ and dominant $(1.5 \mathrm{~cm} / \mathrm{s})$ apparent flow velocities are relevant for the conditions of mean discharge of underground continuation of the Farovščica sinking stream. In the described tracer test defined velocity of this underground flow (partly through Upper Triassic and Lower Jurassic dolomite and partly through Lower-Middle Jurassic limestone) is slightly lower than the average velocity $(2.0 \mathrm{~m} / \mathrm{s})$ defined with previous tracing experiments in Dinaric karst in Slovenia (Novak 1990) but higher than the velocity of underground water flow between Križna jama and Šteberščica $(0.9 \mathrm{~cm} / \mathrm{s})$ traced in similar hydrological conditions by Novak (1965). We can conclude that dolomites between Bloke plateau and Cerknica polje do not function as hydrogeologic barrier at low and mean discharges. An additional tracer test at high water level should be done to test the hydrological function of dolomites also at higher discharges.

The unexpected result of the tracer test was a small amount of tracer detected in Križna jama. Namely, the highest computed hydraulic gradient, wide and long horizontal epiphreatic passages and its position close to the straight line Farovščica ponor-Šteberščica spring would suggest underground flow to Križna jama. After the first positive sample in Mrzla jama the tracer was detected 94 to 102 hours after injection almost simultaneously at all springs (Šteberščica, Žerovniščica, Izvir v Podložu), but not in Križna jama. Even more, at all these points maximum concentration of tracer was reached 95 to 117 hours after the injection and at that time a tracer wave already passed-by Križna jama. The first appearance of tracer in Križna jama (114 hours after injection) is in accordance with rainfall 80-90 hours after the injection. It is possible that the entire quantity of tracer would by-pass Križna jama if there were no rain between $7^{\text {th }}$ and $8^{\text {th }}$ December 2007 . Rain certainly raised water level in the highly dolomitic aquifer but definitely not nearby Križna jama, which has a long, nearly horizontal and well permeable main channel (at high water level it can transfer more than $4 \mathrm{~m}^{3} / \mathrm{s}$ of water with less than $2 \mathrm{~m}$ rise of water at 1 . jezero). Consequently we suppose at higher water level a higher tendency of water flow toward Križna jama, which could drain the surrounding area "contaminated" with tracer previously stored in fis- 
sures. Recession of water level reestablishes the primary water courses and Križna jama drains mainly percolating water. To confirm this additional tracer test at low water level should be carried out. If this interpretation is correct, Križna jama and Križna jama 2 are severely endangered from the possible pollution at the Bloke plateau at higher water levels, when the caves are recharged by contaminated water from broader part of the aquifer. This was already indicated by polystyrene finding in Križna jama, which entered the cave at high water levels only through high-flow ponors of Farovščica. If this interpretation is correct, observations by cavers at different water level and results of sampling at numerous points between injection point (ponor) and springs show on high complexity of underground water flow in this aquifer. Pathways for water can change significantly regarding to water level and the portion of water which sink at ponor and reappear in cave can vary considerably.

To verify these conclusions additional research with tracer tests at low and high waters is necessary. And to assess the impact of outflow from the water treatment plant a detailed monitoring of selected chemical parameters in the water flow in Križna jama at different hydrological conditions should be performed.

\section{ACKNOWLEDGEMENT}

The tracer test was financially supported by the Ministry of Environment and Spatial Planning of the Republic of Slovenia. We also appreciate the help of guides in Križna jama that helped us with many observations and with sampling in Križna jama.

\section{REFERENCES}

Buser, S., 1968: Osnovna geološka karta SFRJ, list Ribnica 1:100000.- Zvezni geološki zavod, Beograd.

Buser, S., Grad, K. \& M. Pleničar, 1967: Osnovna geološka karta SFRJ, list Postojna 1:100.000.- Zvezni geološki zavod, Beograd.

Culver, D. \& B. Sket, 2000: Hotspots of Subterranean Biodiversity in Caves and Wells.- Journal of Cave and Karst Studies 62, 1, 11-17.

Dreybrodt, W., 1988: Processes in Karst Systems (Physics, Chemistry, and Geology).- Springer-Verlag, p. 288, Berlin/Heidelberg/New York/London/Paris/ Tokyo.

Dreybrodt, W., 2000: Equilibrium Chemistry of Karst Water in Limestone Teranes.- In: Speleogenesis, 126-135, Huntsville.

Gospodarič, R., 1974: Fluvialni sedimenti v Križni jami (Fluvial sediments in Križna jama).- Acta carsologica, 4, 325-366, Ljubljana.

Gospodarič, R. \& P. Habič, 1976 (ed.): Underground Water Tracing. Investigations in Slovenia 19721975.- Institute for Karst Research SAZU, p. 312, Ljubljana.
Käss, W., 1998: Tracing technique in Geohydrology.A.A. Balkema, p. 581, Rotterdam, Brookfield.

Kogovšek, J., 1998: Osnovne fizikalno kemične značilnosti kraških voda na Notranjskem.- Acta carsologica, 27, 2, 199-220, Ljubljana.

Novak, D., 1966: Poročilo o barvanju v Križni jami 1965.Naše jame, 8, 1-2, 89, Ljubljana.

Novak, D., 1969: O barvanju potoka v Križni jami.- Geografski vestnik, 41, 75-79, Ljubljana.

Novak, D., 1990: Novejša sledenja kraških voda v Sloveniji po letu 1965.- Geologija, 33, 461-478, Ljubljana.

Prelovšek, M., Turk, J. \& F. Gabrovšek, 2008: Hydrodynamic aspect of caves.- International Journal of Speleology, 37, 1, 11-26, Bologna. 
